\title{
THE DETERMINANT FACTORS OF EARNINGS QUALITY AND ECONOMIC CONSEQUENCES
}

\author{
Gagaring Pagalung \\ gpagalung@yahoo.com \\ Department of Accounting, Hasanuddin University \\ Bambang Sudibdyo \\ Department of Accounting, Gadjah Mada University
}

\begin{abstract}
ABSTRAK
Penelitian ini bertujuan untuk mendiskusikan faktor-faktor penentu kualitas laba dan konsekuensi ekonomi di pasar modal Indonesia. Faktor-faktor tersebut adalah bawaan, kinerja, risiko perusahaan, dan risiko industri. Kualitas earning diukur menggunakan atribut kualitas akrual, persistensi, prediktabilitas, kelancaran, dan kualitas earning faktorial, sedangkan konsekuensi ekonomi diukur menggunakan varians residual sekuritas. Penelitian ini menggunakan data sekunder berupa laporan keuangan perusahaan mulai tahun 2005 hingga 2010. Penelitian menggunakan tiga langkah pengujian, yaitu (1) pengujian atribut kualitas earning yang berbeda satu sama lain, (2) menganalisis faktor-faktor penentu kualitas earning dan (3) menguji pengaruh kualitas earning di pasar saham dalam konteks hubungan antara informasi asimetris dan kualitas earning. Hasil pengujian pertama menunjukkan bahwa semua dari empat atribut kualitas earning berbeda satu sama lain. Analisis faktor-faktor penentu menunjukkan bahwa variabel leverage memiliki hubungan yang signifikan dengan lima atribut kualitas earning, daripada penjualan dan ukuran perusahaan yang menunjukkan hubungan signifikan dengan empat atribut kualitas informasi earning. Variabel lain seperti siklus operasi, kinerja, dan klasifikasi industri menghasilkan dua atribut kualitas earning. Pengujian konsekuensi ekonomi menghasilkan tiga atribut kualitas laba yang memiliki hubungan signifikan dengan varians residual sekuritas yaitu atribut kualitas akrual, kelancaran, dan kualitas laba faktorial.
\end{abstract}

Kata kunci: Kualitas earning, faktor bawaan, risiko perusahaan, risiko industri, varians residual sekuritas

\begin{abstract}
The research aimed to discuss the determinant factors of earnings quality and the economic consequences in Indonesian capital market. Those factors are innate, performance, company risk and industry risk. The quality of earnings was measured using attributes are accrual quality, persistence, predictability, smoothness, and the quality of factorial earnings, whereas the economic consequence was measured using security residual variance. The research employed the secondary data in the form of financial statement of the companies starting from 2005 until 2010. The research employed three steps of testing, namely (1) testing of the attributes of earnings quality were different from each other, (2) analyzing the determining factors of earnings quality and (3) testing the effect of earnings quality in the stock market in terms of the relationship between information asymmetric and the earnings quality. The result of the first testing showed that all of the four attributes of earnings quality were different from each other. The analysis of determinant factors showed that leverage variable had a significant relationship with five attributes of earnings quality, than sales and firm size showed significant relationship with four attributes of earnings information quality. The other variables such as operation cycle, performance and the classification of the industry resulted in two attributes of earnings quality. The economic consequence testing resulted in three attributes of earnings quality that had a significant relationship with the security residual variance. Those attributes were accrual quality, smoothness, and factorial earnings quality.
\end{abstract}

Keywords: Earnings quality, innate factors, company risk, industry risk, security residual variance 



\section{INTRODUCTION}

So far, the financial statements produced by companies are employing accrualbased accounting due to its relevance to the measurement of company financial performance, (Dechow, 1994; Dechow et al., 1998; Palepu et al., 2000; Dechow and Dichev, 2002), its ability to show the realfinancial condition and to predict the future cash flow, and its ability to predict the movement of the future stock price (Chan et al., 2001).

This is supported by Financial Accounting Standard Board by stating that the Information about enterprise earnings and its components measured by accrual accoun ting generally provides a better indication of enterprise performace than does information about current cash receipts and payments (SFAC No.1 paragraf 44). Moreover, the Financial Accounting Standard also states that earnings information was oftenly used as the measurement of company performance as well as other measurements such as return on investment and something related to earnings per share.

The earnings information resulted from the accrual accounting is closely related to the earnings quality (Dechow and Dichev, 2002), which are very important for the users of financial statements such as the investor and creditor who use it as the basic of economic decision making especially those related to contracting decision and investment decision. In additon, the financial statement can also be used, indirectly, as one of the quality indicators of financial reporting standard as made by the standard setters (Collins and Hribar, 2000; Ball and Shivakumar, 2002).

The perspective of contracting decision, the quality of earnings can be used to make decisions related to corporate governance practices. In addition, it can also be used as the basis determine the company's salary allocation (Schipper, 2004). The low-quality earnings only causes unexpected transfer of prosperity, for example if the company employed the overstated earnings as the indicators of manager's performance, overcompensation may happen.

The perspective of investment decision making, it is important for the investors to know the company's earning quality so as to enable them to reduce the information risk (Schipper, 2004). The investors tend to calculate the information risk by analysing the financial information so that the information does not contain a major risk of loss. Investors do not expect the low-quality earnings information because it indicates that there is a poor resource allocation.

Therefore, it can be concluded that the high-quality earnings information earnings its a sign for reducing the information risk. The investors seek for the minor information risk. This information can be seen from how good the quality of company's earnings is (Chan et al., 2001; Boonlert-UThai, 2004; Christensen et al., 2008; Amstrong et al., 2011).

The earnings quality is an important part of financial reports as contained in the obtained company's earnings. This happens because the investors are going to buy the future earnings coming from earnings of the current year reported by the company. The cases of multinational company such as Enron, World Com, and Xerox are the concrete cases related to the problem of earnings quality. The problem is 'is the quality current earnings good?' The current earnings is said to be good in quality if the earnings can be used as the reliable indicators for the future earnings (Penman, 2003) or have a strong association with the future operating cash flow (Cohen, 2003). Therefore, the company can make the proper accounting policy so that the obtained earnings is high in quality which results in the sustainable company's operation.

The researches on earnings quality were conducted using two kinds of approaches (Francis et al., 2004). The first approach is the research related to the factors trigerring the quality earnings and the second approach is how far the user of financial statements respond to the quality of ear- 
nings information. The first approach is related to the study of determining factors which result in the earnings quality. The focus of this approach is the internal factors of the company which is related to the inherent or intrinsic factors of the company itself. That is why this factors are called firm spesifics or firm characteristics. The second approach is related to external factors as the response of the users of financial information or statements. One of the primary users is the investors. They need the information to reduce information asymmetric. The less the information asymmetric, the more similar the information obtained or accessed by the investors. It implies that the private information can be reduced or even omitted.

The factors determining the earnings quality consist of some influencing factors such as innate factors, past performance, intitution risk, and environmental risk. The economic consequence of earnings quality is the investor reaction in the form of investment decision made by the investors in the stock market. The reaction can be in the form of the reaction between the earnings quality and the information asymmetric, which in turn will affect the cost of capital of the company (Barone, 2002; Barth et al., 2001; Barth and Landsman, 2003; Francis et al., 2003a, 2003b; Cohen, 2003). The theory of economics states that, ceteris paribus, increasing the quality of financial information reduces information asymmetries and hence lowers the cost of capital (Diamond and Verrechia, 1991; Easley and O'Hara, 2003; and Cohen, 2003)

One of the economic consequences of financial information happened in the stock market is the stock liquidity. (Healy and Palepu, 2001; Brief, 2002). The stock liquidity plays a significant role because it is capable of reducing the information asymmetries between informed investor and uninformed investor. The increasing stock liquidity in the stock market implies the fair price as stated by Diamond and Verecchia
(1991) and also by Kim and Verecchia (1994).

The motivation of the reseach is trying to study the issues related to the earnings quality of a company focusing on the determinant factors and the economic consequences. The research is also trying to measure the earnings quality using the accounting-based attributes for most researes on earnings quality measurement conducted in Indonesia used market-based attributes such as value relevance and earnings response coefficient. In addition, the research is also trying to offer and study the alternative attribute of earning quality. It was presented as the factor analysis of four attributes of earnings quality which in turn is called factorial earning quality.

Based on the introduction explained previously, the problems of the research were related to what determinant factors influencing the earnings quality of a company and how far/what economic consequences happen in the securiy mar ket in the form of the effect of market liquidity in that market. To be specific, the research tried to answer the questions as the followings:

1. Do the attributes of accounting-based earnings quality such as accrual quality, persistance, predictability and smoothness represent the earnings quality? Do they differ from each other?

2. What factors are influencing the earnings quality of a company?

3. Is there any association between the earnings quality and the information asymmetry?

4. Do the attributes of earnings quality differ from each other when associating with the information asymmetry?

\section{THEORETICAL REVIEW}

Earnings quality, determinant factors and economic consequences

There are some definitons of earnings quality but basically those definitions have two perspectives. The first perspective states that the earnings quality is closely 
related to the company performance as shown by the obtained earnings in the current year.

The earnings quality is considered high if the earnings in the current year can be used as the indicator to predict the future earnings (Penman and Zhang, 2002; Lev and Thiagarajan, 1993; Richardson, 2003) or strongly associated with the future opera- ting cash flow (Cohen, 2003; Dechow and Dichev, 2002). This perspective shows that the focus of measuring the earnings quality is closely related to the characteristics of the financial statements. The second perspective believes that the earnings quality is closed connected to the performance of company's stock in the stock market.

Table 1

The attributes of earnings quality and its Measurements

\begin{tabular}{|c|c|c|c|}
\hline No & Attributes & Measurements & Researcher \\
\hline 1 & $\begin{array}{l}\text { Accrual } \\
\text { Quality }\end{array}$ & $\begin{array}{l}\text { Mapping the current accrual } \\
\text { towards the past, present and } \\
\text { future cash flow }\end{array}$ & $\begin{array}{l}\text { Dechow and Dichev (2002); } \\
\text { Largay III (2002); Francis et } \\
\text { al. (2003a, 2003b, 2004); } \\
\text { Chambers (2003) }\end{array}$ \\
\hline 2 & Persistance & $\begin{array}{l}\text { The regression coefficient of } \\
\text { current earnings towards the } \\
\text { future earnings (Model AR1) }\end{array}$ & $\begin{array}{l}\text { Francis et al. (2003b, 2004), } \\
\text { Sloan (1996) }\end{array}$ \\
\hline 3 & Predictability & $\begin{array}{l}\text { The standard deviation of } \\
\text { model AR1 error }\end{array}$ & $\begin{array}{l}\text { Lougee and Marquardt } \\
\text { (2002); Francis et al. (2003a); } \\
\text { Brown and Sivakumar (2001) }\end{array}$ \\
\hline 4 & Smoothness & $\begin{array}{l}\text { The ratio of earnings } \\
\text { variability towards the cash } \\
\text { flow variability. }\end{array}$ & Francis et al. $(2003 b, 2004)$ \\
\hline 5 & $\begin{array}{l}\text { Value } \\
\text { Relevance }\end{array}$ & $\begin{array}{l}\text { The explanatory power or } \\
\text { degree of Return Regression } \\
\text { towards Earnings }\end{array}$ & $\begin{array}{l}\text { Francis et al. (2003b, 2004); } \\
\text { Brown and Sivakumar (2001) }\end{array}$ \\
\hline 6 & Timeliness & $\begin{array}{l}\text { The explanatory power or } \\
\text { degree of earning reversal } \\
\text { regression towards return }\end{array}$ & Francis et al. $(2003 b, 2004)$ \\
\hline 7 & Conservatism & $\begin{array}{l}\text { The ratio of reversal } \\
\text { regression coefficient } \\
\text { towards the negative return } \\
\text { in the positive return } \\
\text { coefficient }\end{array}$ & Francis et al. $(2003 b, 2004)$ \\
\hline 8 & $\begin{array}{l}\text { Earnings } \\
\text { Quality Index }\end{array}$ & $\begin{array}{l}\text { The combination of change in } \\
\text { the conservatism score and } \\
\text { the comparison of } \\
\text { conservatism score in the } \\
\text { company industry median }\end{array}$ & Penman and Zhang (2002) \\
\hline 9 & $\begin{array}{l}\text { The } \\
\text { Information } \\
\text { contained }\end{array}$ & $\begin{array}{l}\text { The explanation degree and } \\
\text { the earnings regression } \\
\text { coefficient }\end{array}$ & Brown and Sivakumar (2001) \\
\hline 10 & $\begin{array}{l}\text { Abnormal } \\
\text { accrual }\end{array}$ & $\begin{array}{l}\text { The total accrual towards the } \\
\text { property, plant and } \\
\text { equipment }\end{array}$ & Francis et al (2003a) \\
\hline
\end{tabular}


Table 2

The determinant factors of earnings quality and its Measurements

\begin{tabular}{|c|c|c|c|c|}
\hline No & $\begin{array}{l}\text { The Determinant } \\
\text { Factors }\end{array}$ & The Measurements & Sign & Researchers \\
\hline 1 & Operation Cycles & $\begin{array}{l}\text { The amounts of } \\
\text { receivables and } \\
\text { inventory turnovers }\end{array}$ & $+(-)$ & $\begin{array}{l}\text { Dechow (1994); Gu et al. } \\
\text { (2002); Francies et al. } \\
\text { (2004); Francis et al. (2003b) }\end{array}$ \\
\hline 2 & Sales Volatility & $\begin{array}{l}\text { The standard deviation } \\
\text { of sales per total assets }\end{array}$ & $+(-)$ & $\begin{array}{l}\text { Dechow and Dichev (2002); } \\
\text { Francis et al. (2003b) }\end{array}$ \\
\hline 3 & Company Size & Log of total assets & $+(-)$ & $\begin{array}{l}\text { Dechow and Dichev (2002); } \\
\text { Gu et al. (2002); Francis et } \\
\text { al. (2003b); Cohen (2003) }\end{array}$ \\
\hline 4 & Company Age & $\begin{array}{l}\text { The difference between } \\
\text { the year of observation } \\
\text { and when the company } \\
\text { was established }\end{array}$ & - & $\begin{array}{l}\text { Gu et al. (2002); McNichols } \\
\text { (2002) }\end{array}$ \\
\hline 5 & Performance & $\begin{array}{l}\text { The proportion of loss } \\
\text { for } 4 \text { years of } \\
\text { observation }\end{array}$ & $+(-)$ & $\begin{array}{l}\text { Dechow and Dichev (2002); } \\
\text { Francis et al. (2003b); Hyan } \\
\text { (1995); DeFond and Park } \\
\text { (2001) }\end{array}$ \\
\hline 6 & Liquidity & $\begin{array}{l}\text { The ratio of current } \\
\text { assets devided by } \\
\text { current liability }\end{array}$ & + & Francis et al. (2003b) \\
\hline 7 & Leverage & $\begin{array}{l}\text { The total liability } \\
\text { devided by the total } \\
\text { assets }\end{array}$ & + & $\begin{array}{l}\text { Cohen (2003); Gu et al. } \\
\text { (2002); Easley et al. (2002); } \\
\text { Easley and O'Hara (2003) }\end{array}$ \\
\hline 8 & $\begin{array}{l}\text { Industry } \\
\text { Classification }\end{array}$ & $\begin{array}{l}\text { The classification of } \\
\text { industries listed in the } \\
\text { Jakarta Stock Exchange }\end{array}$ & + & Gu et al. (2002) \\
\hline
\end{tabular}

The stronger the relationship between the earnings and the market returns, the higher the earnings quality (Chan et al, 2001; Lev and Thiagarajan, 1993). Therefore, the earnings quality is the construct that can be analysed using two perspectives.

Those are the earnings quality which is related to the cash and the earnings themselves or the earnings quality which is related to the stock return. Those constructs of earnings quality could not be observed directly, instead it can be observed and measured using proxis or attributes contained in the earnings itself.

Tabel 1 presents the summary of attri- butes of earnings quality employed in the research.

The determinant factors of earnings information are the factors influencing the earnings quality. Those factors consist of innate or intrinsic factors which originally come from the enviroment where the company operates and the other factors influencing the degree of company discretionary. Those determinant factors varies greatly from one research to another depending on the purpose or the research itselt. The following table presents the summary of the results of the previous researches on the determinants factors of earnings quality. 
The earnings information resulted from the accrual accounting process will be very useful as long as it is used as the primary sources of information in decision making made by the users of financial statements. The investors as one of the primary user will consider and analyse the information so as to make favorable investment decision (Fairfield and Yohn, 2000). How far the investor response towards the earnings information shows whether or not an investment decision have considered the earnings information as the primary source of information. In the context of the response, there are two primary conditions to be fulfilled to make the information effective as the primary source of information so that it will be usefull for the investors to make decision. The first condition is the information presented is easily accessed and broadly distributed to the investors. The absence of this condition only results in information assymetry. The second condition is the information contains a minor information risk

The information about the degree of information assymmetry is the private information of informed investors, whereas the other investors (uninformed investor) do not have such information. In other words, there is imbalance in obtaining and possessing information. In this condition, the informed investors has more favorable condition for having such private infor mation. The information assymetry can cause trade imbalance so that the earnings will be obtained only by certain investors. One way to reduce the information assymetry is by revealing the qualified information. The research offers the way of revealing qualified information by increasing the company's earnings quality. Some researches have proven that increasing the earnings quality is capable of reducing the information assymetry which in turn establishes the market liquidity (Leuz and Verrechia, 2000; Cohen, 2003).

Dierkens (1991) had observed the relationship between the information assy- metry and the equity issues. The purpose of his research is testing the relevance of information assymetry among the managers and equity market during the process of the announcement of equity issues. There are four proxies of information assymmetry, market reaction on earnings announcement, residual variance of return, amount of publik announcement, and trade intensity. The result of the research is significant relation between information assymmetry and equity issues.

\section{The Formulation of Hypothesis}

The theory of behind the research is the theory about valuation or valuation model (Cornel and Landsman, 2003; Christensen et al., 2005). This model tests the earnings and other accounting information in the current year in order to predict the future earnings. This model had been employed by Dechow (1994), Sloan (1996), Dechow et al. (1998), Dechow and Dichev (2002).

Based on the previous research findings, the hypotheses of this research were formulated as the followings:

$\mathrm{H}_{1}$ : There is no difference among the attributes of the company's earnings quality

$\mathrm{H}_{2 \mathrm{a}}$ : The longer the company operation cycle, the lower the quality of company's earnings

$\mathrm{H}_{2 b}$ : The bigger the volatility magnitude of company sale, the lower the quality of company's earnings

$\mathrm{H}_{2 \mathrm{c}}$ : The bigger the company size, the lower the quality of company's earnings

$\mathrm{H}_{2 \mathrm{~d}}$ : The older the company, the higher the quality of company's earnings

$\mathrm{H}_{2 \mathrm{e}}$ : The low portion of loss positively associated with the high quality of earnings

$\mathrm{H}_{2 \mathrm{f}}$ : The higher the rate of company's liquidity, the higher the quality of company's earnings

$\mathrm{H}_{2 \mathrm{~g}}$ : The higher the rate of company's leverage, the higher the quality of company's earnings 
$\mathrm{H}_{2 \mathrm{~h}}$ : There is a relationship between the earnings quality and the industry classification risk

$\mathrm{H}_{3 \mathrm{a}}$ : The level of the earnings quality is associated with the level of information asymmetry

$\mathrm{H}_{3 b}$ : There is a difference in relationship between the attributes of earnings quality and the level of information asymmetry

\section{RESEARCH METHOD}

\section{The Data and Sample of the Research}

The data employed in this research were totally taken from manufacture companies listed in the Jakarta Stock Exchange. The sampling technique was purposive sampling, focusing on the companies that had been listed in the Jakarta Stock Exchange since 1 January 2005. Therefore, the research employed the secondary data in the form of financial statement of the companies starting from 2005 until 2010.

\section{Research Variables and The Measurements}

The varibles employed in this research consist of those related to the determinant factors of earnings quality and its economic consequences. The variables are the operation cycle, sales volatility, company size, company age, performance, liquidity, leverage and classification of industry. The measurement of the determinant factors is presented in table 2.

The earnings quality is unmeasurable construct directly. However, it can be measured by attaching the attributes of the earnings quality to a certain proxy (Kirschenheiter and Melumad, 2002; Francis et al., 2003b, 2004, Schipper and Vincent, 2003; and Schipper, 2004). The variable of earnings quality in this research was attributed or being proxied based on the accounting attributes, that is accrual quality, persistence, predictability, smoothness and factorial earnings quality. The underlying concept of accrual quality and smoothness is the same, those are earnings and cash flow. On the other hand, the persistence and predictability involved the information on the comparison between last year and current earnings (autoregresive model).

Accrual quality tries to find out how close the cash flow and the accrual. The further it is results in the bigger distortion of recognise cash (Fairfield and Whisenant, 2001). This condition means that the earnings does not reflect the reality (or it can said that the accrual quality is low). On the contrary, the closer it is, the earnings is more powerful in reflecting the reality. The smoothness resulted from the ratio between the earnings deviation standard before the extraordinary accounts per assets devided by the standard deviation of operating cash flow per total assets.

The persistance was measured by observing the value of beta $\left(\beta_{1}\right)$ from the autoregresive equation of annual earnings (model AR1). The higher it is, (the more it is close to 1 ), the higher the resulted coefficient $\left(\beta_{1}\right)$ shows the earnings persistance. On the contrary, the smaller the coefficient of beta (the closer it is to zero), the lower the earnings quality or the higher the transitory earnings. The predictability was measured by observing the error of autoregressive equation of the annual earnings (model AR1) using the formula of the square root of the error variance square $\left(\sqrt{ } \sigma^{2}\left(\gamma_{t}\right)\right)$. The bigger the value of predictability, the less powerful the earnings predicts the future earnings, on the contrary, the smaller the value of predictability, the more powerful the earnings predicts the future earnings.

The measurement of every attributes of earnings quality is presented in the following table. The economic consequence of earnings quality for the investor valuation can be in the form of information asymmetry and equity cost.

Information asymmetry underlines the estimation risk or market liquidity which consider the difference of information possesed by informed investors and uninformed investor. Based on the difference, the uninformed investors expect a higher 
risk premium from acertain portfolio so that there is a balance in the information access (Kamp, 2002).

The information difference is expected to be able to increase the quality and the content of financial information so that it can reduce the information asymmetry (Leuz and Verrechia, 2004; Callahan et al, 1997). The research measured the information asymmetry using the residual variance of stock return as the adjusted market of residual varian of abnormal return on daily stock price in one accounting period (Dierkens, 1991).

\section{The Empirical Model}

The data analysis of this research was conducted in three steps of testing, namely:

Testing if there is no overlapping among the accounting attributes as the proxis of earnings quality. If they are different from each other, the further testing is done by analysing four of the attributes to form one new attribute of earnings quality.

1. Testing if there is no overlapping among the accounting attributes as the proxis of earnings quality. If they are different from each other, the further testing is done by analysing four of the attributes to form one new attribute of earnings quality.
2. Conducting a factor analysis on the determinant factors of earnings quality.

3. Testing the effect of earnings quality in the stock market by studying the economic consequence in the stock market in the form of the relationship between the information asymmetry and the company's earning quality

The first analysis was conducted by testing the auxiliary regression (Gujarati, 2003) that is a regression which applies one attribute of earnings quality as the dependent variable towards other earnings quality attributes as the independent variable which later on produces the auxiliary $\mathrm{R}^{2}$ (Francis et al., 2003b, 2004).

As for the testing of determinant factors of earnings quality, the research conducted the testing using the regression equation as the followings:

$\mathrm{KL}_{\mathrm{n}, \mathrm{t}}=\mathrm{a}_{0}+\beta_{1}$ operating cycle $\mathrm{t}+\beta_{2}$ sale $_{\mathrm{t}}+$ $\beta_{3}$ size $_{t}+\beta_{4}$ age $_{t}+\beta_{5}$ performance $+\beta_{6}$ Liquidity $+\beta_{7}$ Leverage $t+\beta_{8}$ industry classification $_{\mathrm{t}}+\varepsilon_{\mathrm{t}} \ldots \ldots$ (1)

$\mathrm{KL}_{n, t}$ consists of :

$\mathrm{KL}_{1, \mathrm{t}}=$ accrual quality;

$\mathrm{KL}_{2, \mathrm{t}}=$ persistance;

$\mathrm{KL}_{3, \mathrm{t}}=$ predictability;

$\mathrm{KL}_{4, \mathrm{t}}=$ smoothness

$\mathrm{KL}_{5, \mathrm{t}} \quad$ = factorial earnings quality

Table 3

The Attributes of Acconting-based Earnings Quality and Its Measurement

\begin{tabular}{|c|c|c|c|}
\hline No & The Attributes & The Measurement & The Researchers \\
\hline 1 & Accrual Quality & $\begin{array}{l}\text { Mapping the current accrual } \\
\text { towards the past, present and } \\
\text { future cash flow }\end{array}$ & $\begin{array}{l}\text { Dechow and Dichev (2002); } \\
\text { Francis et al. (2003a, 2003b, } \\
\text { 2004); Chambers (2003); }\end{array}$ \\
\hline 2 & Persistance & $\begin{array}{l}\text { The regression coefficient of } \\
\text { current earnings towards the } \\
\text { future earnings (Model AR1) }\end{array}$ & $\begin{array}{l}\text { Lev (1993); Francis et al. } \\
(2003 b, 2004) \text {, Sloan (1996) }\end{array}$ \\
\hline 3 & Predictability & $\begin{array}{l}\text { The standard deviation of } \\
\text { model AR1 error. }\end{array}$ & $\begin{array}{l}\text { Francis et al. (2003a); Brown } \\
\text { and Sivakumar (2001) }\end{array}$ \\
\hline 4 & Smoothness & $\begin{array}{l}\text { The ratio of earnings } \\
\text { variability towards the cash } \\
\text { flow variability. }\end{array}$ & $\begin{array}{l}\text { Miller (2002); Francis et al. } \\
(2003 b, 2004) \text {; }\end{array}$ \\
\hline
\end{tabular}


The economic consequence of earnings quality for the investor valuation can be in the form of information asymmetry and equity cost. Information asymmetry underlines the estimation risk or market liquidity which consider the difference of information possesed by informed investors and uninformed investor. Based on the difference, the uninformed investors expect a higher risk premium from a certain portofolio so that there is a balance in the information access (Kamp, 2002). The information difference is expected to be able to increase the quality and the content of finan cial information so that it can reduce the information asymmetry (Leuz and Verrechia, 2004; Callahan et al, 1997). The research measured the information asymmetry using the residual variance of stock return as the adjusted market of residual varian of abnormal return on daily stock price in one accounting period (Dierkens, 1991).

The third step of analysis was testing the relationship between the attributes of earnings quality and the information asymmetry using the multivariat regression as the followings:

$\mathrm{VR}_{1, \mathrm{t}}=\alpha_{0}+\beta_{1} \mathrm{KL}_{\mathrm{n}, \mathrm{t}}+\beta_{2}$ Leverage $_{\mathrm{t}}+\beta_{3}$ Beta $_{t}+\beta_{4}$ Size $_{t}+\varepsilon_{t} \ldots \ldots$. . (2)

$\mathrm{VR}_{1, \mathrm{t}}=$ the variance of security residual

$\mathrm{KL}_{1, \mathrm{t}}=$ accrual quality

$\mathrm{KL}_{2, \mathrm{t}}=$ persistance

$\mathrm{KL}_{3, \mathrm{t}}=$ predictability;

$\mathrm{KL}_{4, \mathrm{t}}=$ smoothness, and

$\mathrm{KL}_{5, \mathrm{t}} \quad$ = factorial earnings residual

The additional testing in third analysis is the testing the superior model among attributes of earnings quality and information asymmetry.

The testing was conducted using NonNested model by applying DavidsonMacKinnon J Test or J test (Gujarati, 2003).

\section{ANALYSIS AND DISCUSSION Testing of Earnings Quality Attributes}

The result of auxiliary regression analysis showed that there was no overlapping among the four variables of earnings quality because the result of correlation attributes were less than 0,5 (Francis et al. 2003b, 2004, and Gujarati, 2003).

The result of the auxiliary regression is presented in table 4 as the followings:

The results of the testing presents that the accrual quality shows the highest value of auxiliary $\mathrm{R}^{2}(0,45)$, followed by predictability $(0,31)$, smoothness $(0,23)$, and persistance $(0,01)$. This result confirms the research result conducted by Francis et al. (2004) which obtained the highest value of auxiliary $\mathrm{R}^{2}$ of 0,27 . However, the attribute of persistance obtained the smallest value of auxiliary $\mathrm{R}^{2}$ of 0,01 . Therefore, it could be concluded that the attribute of persis- tance is more likely to overlap with the other three attributes of earnings quality since it only had $2 \%$ of coverage.

The factor analysis of the four earnings quality attributes resulted in the followngs:

The four original variables mentioned above formed one factor which is significantly influenced by the attributes of accrual quality $(0,864)$, predictability $(0,735)$ and smoothness $(0,729)$ (see panel $C$ ). The attribute of persistance did not have any influence in forming the new factor since the score was too small $(-0,201)$. Intuitively, the formation of the new factor was influenced by the three attributes of earnings quality namely accrual quality, predictability and smoothness. Two of the attributes, accrual quality and smoothness have the same formula focusing on the earnings variability, that is the comparison between the earnings and the operating cash flow. 
Table 4

Correlation matrix of earnings quality attributes

\begin{tabular}{lllllc}
\hline \hline & $\begin{array}{l}\text { Accrual } \\
\text { Quality }\end{array}$ & Persistance & Predictability & Smoothness & $\begin{array}{l}\text { Auxiliary } \\
\boldsymbol{R}^{2}\end{array}$ \\
\hline Accrual Quality & 1,000 & $-0,105$ & 0,548 & 0,508 & $0,451^{*}$ \\
Persistance & $-0,111$ & 1,000 & $-0,016$ & $-0,100$ & $0,016^{*}$ \\
Predictability & 0,534 & $-0,018$ & 1,000 & 0,276 & $0,303^{*}$ \\
Smoothness & 0,518 & $-0,100$ & 0,245 & 1,000 & $0,237^{*}$ \\
\hline
\end{tabular}

* signifance level of $1 \%$

** signifance level of $5 \%$

*** signifance level of $10 \%$

Table 5

The factor analysis of the four earnings quality attributes

\begin{tabular}{|c|c|c|c|c|}
\hline \multicolumn{5}{|c|}{ A. Communalities of the four earnings information attributes: } \\
\hline Variables & Accrual Quality & Persistance & Predictabilty & Smoothness \\
\hline Communalities & 0,768 & 0,040 & 0,566 & 0,532 \\
\hline \multicolumn{5}{|c|}{ B. Eigenvalues for reducing the correlation matrix: } \\
\hline Factor & 1,000 & 2,000 & 3,000 & 4,000 \\
\hline Eigenvalues & 1,922 & 0,995 & 0,724 & 0,269 \\
\hline \multicolumn{5}{|l|}{ C. The component Matrix: } \\
\hline Indicator & Accrual Quality & Persistance & Predictability & Smoothness \\
\hline Component/Factor 1 & 0,864 & $-0,201$ & 0,735 & 0,729 \\
\hline
\end{tabular}

Table 6

Descriptive Statistics of the Research Variables

\begin{tabular}{llrrr}
\hline \hline \multicolumn{1}{c}{ Variables } & $\mathbf{N}$ & Mean & Median & $\begin{array}{r}\text { Standard } \\
\text { Deviation }\end{array}$ \\
\hline Accural Quality & 464 & 0,224 & 0,156 & 0,179 \\
Persistance & 464 & $-0,043$ & $-0,024$ & 0,361 \\
Predictability & 464 & 0,100 & 0,060 & 0,122 \\
Smoothness & 464 & 3,473 & 1,1532 & 8,132 \\
Factorial Earnings & 464 & $-4,420$ & $-0,272$ & 0,994 \\
Quality & & & & \\
Operation Cycle & 464 & 2,307 & 2,168 & 0,433 \\
Sales & 464 & 0,911 & 0,748 & 0,568 \\
Size & 464 & 11,704 & 11,762 & 0,574 \\
Company Age & 464 & 24,918 & 24,000 & 10,590 \\
Performance & 464 & 0,324 & 0,248 & 0,306 \\
Liquidity & 464 & 3,690 & 1,233 & 27,724 \\
Leverage & 464 & 0,736 & 0,674 & 0,549 \\
Industry & 464 & 0,250 & 0,000 & 0,436 \\
Classification & & & \\
\hline
\end{tabular}

The Result of Testing the Determinant Factors of Earning Quality 


\section{The Result of Testing the Determinant Factors of Earning Quality. \\ Deskriptive Statistics}

The descriptive statistics of testing the determinant factors of earnings quality resulted in the followings:

This testing employed Multivariate Regression Analysis. Therefore, a model assump tion testing or classical assumption was priorly conducted.

This test consisted of the testing of linearity, multicolinearity, heteroskedasticity, autocorrelation, and the testing of the normality of the predicted value of residuals of each model.

The following table presents the result of regression testing of the determinant factors of earnings quality.

Table 7 presented above shows the factor of operation cycle negatively asso- ciated with all of the attributes of earnings quality, but only the attribute of persistence and factorial earnings quality which were statistically significant. The coefficient of significant level for the attribute of persistance was $-0,137(1 \%)$, and the factorial earnings quality was $-0,229(5 \%)$. This result showed that the longer the operation cycle of the company, the lower the quality of earnings, therefore the hypothesis $\mathrm{H}_{2 \mathrm{a}}$ as accepted. This same result were obtained by Dechow and Dichev (2002), Francis et al. (2004), and Gu et al. (2002) showing that the relationship was negative.

The factor of sales volatility varied in its relationship with the other variables. The attributes of accrual quality, smoothness and factorial earnings quality were negative ly related which the coefficient of $-0,034$

Table 7

The Determinant Factors of Earnings Quality

\begin{tabular}{|c|c|c|c|c|c|c|}
\hline $\begin{array}{l}\text { The determinant } \\
\text { factors }\end{array}$ & $\begin{array}{l}\text { Predi } \\
\text { ction }\end{array}$ & $\begin{array}{l}\text { Accrual } \\
\text { Quality }\end{array}$ & Persistance & $\begin{array}{l}\text { Predictabil } \\
\text { ity }\end{array}$ & Smoothness & $\begin{array}{l}\text { Factorial } \\
\text { Earnings } \\
\text { Quality }\end{array}$ \\
\hline Operation Cycle & - & $\begin{array}{l}-0,022 \\
(-0,914)\end{array}$ & $\begin{array}{l}-0,137^{*} \\
(-2,856)\end{array}$ & $\begin{array}{l}-0,001 \\
(-0,138)\end{array}$ & $\begin{array}{l}-1,511 \\
(-1,453)\end{array}$ & $\begin{array}{l}-0,229 \\
(-2,133)\end{array}$ \\
\hline Sales Volume & - & $\begin{array}{l}-0,034^{* *} \\
(-2,334)\end{array}$ & $\begin{array}{l}0,042 \\
(1,204)\end{array}$ & $\begin{array}{l}0,013 * * \\
(1,946)\end{array}$ & $\begin{array}{l}-1,894^{*} \\
(-2,582)\end{array}$ & $\begin{array}{l}-0,178^{*} \\
(-2,439)\end{array}$ \\
\hline Company Size & - & $\begin{array}{l}0,0008 \\
(0,050)\end{array}$ & $\begin{array}{l}-0,0744^{* *} \\
(-1,992)\end{array}$ & $\begin{array}{l}-0,028 * \\
(-3,558)\end{array}$ & $\begin{array}{l}-1,427^{* * *} \\
(-1,848)\end{array}$ & $\begin{array}{l}-0,168 * * \\
(-2,101)\end{array}$ \\
\hline Company Age & + & $\begin{array}{l}-0,0008 \\
(-1,121)\end{array}$ & $\begin{array}{l}-0,003 \\
(-1,496)\end{array}$ & $\begin{array}{l}0,0003 \\
(1,346)\end{array}$ & $\begin{array}{l}0,038 \\
(1,015)\end{array}$ & $\begin{array}{l}0,001 \\
(0,281)\end{array}$ \\
\hline Performance & - & $\begin{array}{l}0,055^{* *} \\
(1,932)\end{array}$ & $\begin{array}{l}-0,002 \\
(-0,031)\end{array}$ & $\begin{array}{l}0,095^{*} \\
(6,949)\end{array}$ & $\begin{array}{l}0,953 \\
(0,677)\end{array}$ & $\begin{array}{l}0,017 \\
(0,125)\end{array}$ \\
\hline Liquidity & + & $\begin{array}{l}0,0001 \\
(0,485)\end{array}$ & $\begin{array}{l}0,0001 \\
(0,173)\end{array}$ & $\begin{array}{l}0,0002^{* * *} \\
(1,801)\end{array}$ & $\begin{array}{l}-0,009 \\
(-0,702)\end{array}$ & $\begin{array}{l}0,0002 \\
(0,172)\end{array}$ \\
\hline Leverage & + & $\begin{array}{l}0,137^{*} \\
(9,077)\end{array}$ & $\begin{array}{c}-0,084 \\
(-2,512)\end{array}$ & $\begin{array}{l}0,062^{*} \\
(4,3659)\end{array}$ & $\begin{array}{l}3,588^{*} \\
(4,901)\end{array}$ & $\begin{array}{l}0,934^{*} \\
(12,203)\end{array}$ \\
\hline $\begin{array}{l}\text { Industry } \\
\text { Classification }\end{array}$ & $+/-$ & $\begin{array}{l}-0,052 * \\
(-3,065)\end{array}$ & $\begin{array}{l}0,050 \\
(1,176)\end{array}$ & $\begin{array}{l}-0,006 \\
(-1,010)\end{array}$ & $\begin{array}{l}-1,136 \\
(-1,301)\end{array}$ & $\begin{array}{l}-0,143^{* * *} \\
(-1,668)\end{array}$ \\
\hline Adjusted $\mathbf{R}^{2}$ & & $0,239^{*}$ & $0,032^{*}$ & $0,221^{*}$ & $0,085^{*}$ & $0,327^{*}$ \\
\hline
\end{tabular}

Notes:

* significant level of $1 \%$

** significant level of $5 \%$

*** significant level of $\mathbf{1 0} \%$ 
(5\%), $-1,894(1 \%)$, and $-0,178(1 \%)$, while the positive relationship were shown by the attribute of predictability with the coefficient of $0,013(5 \%)$.

This result showed that the hypothesis $\mathrm{H}_{2 b}$ stating that greater the magnitude of sales volatility, the lower of earnings quality was accepted. The same result was also found by Dechow and Dichev (2002), while the statement the greater the sales volatility the higher the earnings quality was firstly stated by Francis et al. (2004) and Willekens (2006). In this research, it is the same as the attribute of predictability.

The factor of company size showed a negative relationship towards the attributes of persistance, predictability, smooth ness and factorial earnings quality which the coefficients were subsequently $-0,074$ $(5 \%),-0,028(1 \%),-1,427(10 \%)$, and $-0,168$ $(10 \%)$. This result proved the hypothesis $\mathrm{H}_{2 \mathrm{c}}$ stating that the bigger the company the lower the earnings quality. This result also supports the result of the previous researches (Francis et al, 2004, Gu et al, 2002, Cohen, 2003). The factor of company age showed that all atrributes of earning quality did not significantly related so that it was too difficult to intepret. It might happen because the measurement of the variable of company age was conducted improperly.

The factor of company performance resulted in the positive relationship for accrual quality with the coefficient of 0,055 $(5 \%)$, and the predictability with the coefficient of $0,095(1 \%)$. The factor of liquidity showed that only the attribute of predictability which had a significant relation ship with the coeffiecient of 0,0002 in the significant level of $10 \%$. Intuitively, the determinant factors of company age and liquidity showed unstable result due to most of the factors were not significant and only a small number of empirical research showed the good results for this testing.

The factor of leverage showed that all of the attributes were significant and had a positive relationship except for persistance. The coefficients obtained were subsequently
$0,139(1 \%)$ for accrual quality, 0,062 (1\%) predictability, 3,588 (1\%) for smoothness, and $0,934(1 \%)$ for factorial earnings quality, while the persistance had the coeficient of $0,062(1 \%)$. This result proved that the higher the level of leverage of a company, the higher the earnings quality. Therefore, the hypothesis $\mathrm{H}_{2 \mathrm{~g}}$ was accepted. This result also supports the results of the previous research like the one conducted by Cohen (2003), Gu et al. (2002), Hoitash et al. (2002), and Francis et al. (2004).

The factor of industry classification showed a negative relationship for the attribute of accrual quality and the factorial earnings quality. The coefficient resulted were subsequently $-0,056(1 \%)$ for the accrual quality and $-0,152(10 \%)$ for the factorial earnings quality. The negative relationship resulted from the determinant factors of industry classification showed a different result from the research done by $\mathrm{Gu}$ et al, (2002). Therefore, the hypothesis $\mathrm{H}_{2 h}$ about the relationship between the classification industry and the earnings quality was accepted, especially for the attributes of accrual quality and the factorial earnings quality.

The Results of Testing The Economic Consequence of Earnings Quality Descriptive Statistics

The following table presents the descriptive statistics of testing the economic consequence of earnings quality.

\section{The Result of Testing The Economic Consequence of Earning Quality}

The classic assumption of regression analysis on the economic consequence of earnings quality showed that there was no serious problem except for the attribute of predictability and the factorial earnings quality which underwent heteroskedasticity although it had been solved.

Table 9 below presents the result of testing the economic consequence of earnings quality. The testing of economic consequence among the security residual variance and the attributes of earnings 
quality showed that only the accrual quality (model 1), smooth- ness (model 4), and factorial earnings quality (model 5) were significant, while the attribute of persistance (model 2) and predictability (model 3) were not significant. The coefficient resulted from model 1 was $0,036(1 \%)$, model 4 was 0,049 $(1 \%)$, and model 5 was 0,005 (1\%). Therefore, the hypothesis $3 a$ was accepted for the attributes of accrual quality, smoothness and factorial earnings quality.

The Comparison of The Models of Economic Consequence of Earnings Quality

The comparison was conducted using non nested hypothesis testing especially Davidson-MacKinnon $J$ test or $J$ testing (Gujarati, 2003:533). The result of $J$ testing showed that the accrual quality (model 1) was superior to the smoothness (model 4) and factorial earnings quality (model 5). This findings was drawn from the result that the hypothesis stating that model 1 is superior to model 4 and model 5 was accepted. Meanwhile, model 4 and model 5 did not superior to each other since the hypothesis stating so was rejected. Therefore, it can be concluded that the attribute of accrual quality was more superior to the other attributes of earnings quality such as smoothness and factorial earnings quality in the economic consequence of earnings quality testing.

\section{Discussion of The Research Results Earnings Quality}

The analysis of auxiliary regression showed that the four measurements of accounting-based earnings quality were different from each other. The attribute of persistance had the lowest correlation while the others were high. This result reflected that the attribute of persistance had the possibility of being overlapped with the other measurements of earnings quality.

The altenative earnings quality resulted from the factor analysis of the four attributes produced three attributes of earnings quality contributing to the formation of alternative earnings quality. They were accrual quality, predictability, and smoothness, while the attribute of persistance gave a tiny contribution. Therefore, it can be concluded that the measurement of the attributes of earnings quality was dominated by the measurement of the earnings variability which defines the earning quality as the closeness between the earnings and the cash flow.

Table 8

The Descriptive Statistics of The Economic Consequence of Earnings Quality

\begin{tabular}{lcccc}
\hline \hline \multicolumn{1}{c}{ Variables } & N & Mean & Median & Standard Deviation \\
\hline Varresid & 116 & 0,040 & 0,032 & 0,021 \\
Kuakrual & 116 & 0,232 & 0,136 & 0,178 \\
Persisten & 116 & $-0,041$ & $-0,05$ & 0,358 \\
Predikta & 116 & 0,101 & 0,062 & 0,120 \\
Perlaba & 116 & 3,467 & 1,151 & 8,181 \\
Klfaktor & 116 & $-4,403$ & $-0,277$ & 1,000 \\
Sales & 116 & 0,153 & 0,117 & 0,169 \\
Beta & 116 & 2,456 & 2,648 & 0,714 \\
Leverage & 116 & 0,771 & 0,624 & 0,739 \\
\hline
\end{tabular}

Notes:

Varresid= security residual variance, Kuakrual $=$ accrual quality, Persiten $=$ persistance, Predikta = predictability, Perlaba $=$ smoothness, Klfaktor $=$ factorial earnings quality, $\mathrm{N}=$ the number of observation 
The Determinant Factors of Earnings Quality

The research found out that the determinant factor of leverage resulted in the significant relationship with five attributes of earnings quality, followed by the variable of sales volatility and company size which resulted in the significant relationship with four attributes of earnings quality (Richardson et al., 2003). The sales volatility had a negative relationship with the accrual quality, smoothness, factorial earnings quality, and had a positive relationship with predictability. Meanwhile, the company size had a negative relationship with four attributes namely persistance, predictability, smoothness and factorial earnings quality. Therefore, it could be concluded that among eight determinant factors of earnings quality, the factor of leverage, sales volatility and company size were the primary factors, while the other variable varied in terms of their significant level with the other five attributes. For example, the attributes of operation cycle, company performance, and the industry classification showed two attributes of earnings quality that had a significant relationship. On the other hand, the research also found insignificant relation ship built by the eterminant factor, or even had no relationship at all with the five attributes of earnings quality.

The variable of liquidity had a relationship only with the attribute of predictability, while the attribute of company age had no relationship with one of the all attributes of earnings quality. Intuitively, both of the variables which had a loose relationship could be resulted from the unappropriate measurement employed by the research.

Table 9

The Economic Consequence of Earnings Quality

\begin{tabular}{|c|c|c|c|c|c|}
\hline & $\begin{array}{c}\text { Model } 1 \\
\text { (Vr) }\end{array}$ & $\begin{array}{c}\text { Model } 2 \\
(\mathrm{Vr})\end{array}$ & $\begin{array}{c}\text { Model } 3 \\
(\mathrm{Vr})\end{array}$ & $\begin{array}{c}\text { Model } 4 \\
(\text { Vr) }\end{array}$ & $\begin{array}{c}\text { Model } 5 \\
(\text { Vr) }\end{array}$ \\
\hline Accrual Quality & $\begin{array}{c}0,036^{*} \\
(3,505)\end{array}$ & & & & \\
\hline Persistance & & $\begin{array}{l}0,005 \\
(1,046)\end{array}$ & & & \\
\hline Predictability & & & $\begin{array}{l}0,021 \\
(1,131)\end{array}$ & & \\
\hline Smoothness & & & & $\begin{array}{l}0,049^{*} \\
(3,021)\end{array}$ & \\
\hline $\begin{array}{l}\text { Factorial Earnings } \\
\text { Quality }\end{array}$ & & & & & $\begin{array}{l}0,005^{*} \\
(2,429)\end{array}$ \\
\hline Sales & $\begin{array}{l}-0,009 \\
(-0,862)\end{array}$ & $\begin{array}{l}-0,004 \\
(-0,398)\end{array}$ & $\begin{array}{l}-0,008 \\
(-0,678)\end{array}$ & $\begin{array}{l}-0,002 \\
(-0,128)\end{array}$ & $\begin{array}{l}-0,009 \\
(-0,800)\end{array}$ \\
\hline Beta & $\begin{array}{l}-4,29 \\
(-0,015)\end{array}$ & $\begin{array}{l}0,0005 \\
(-0,197)\end{array}$ & $\begin{array}{l}9,020 \\
(0,031)\end{array}$ & $\begin{array}{l}-0,002 \\
(-0,292)\end{array}$ & $\begin{array}{l}0,0002 \\
(-0,101)\end{array}$ \\
\hline Leverage & $\begin{array}{l}-0,004 \\
(1,490)\end{array}$ & $\begin{array}{l}0,007 \\
(3,071)\end{array}$ & $\begin{array}{l}0,005^{* * *} \\
(1,725)\end{array}$ & $\begin{array}{l}0,006^{* *} \\
(1,937)\end{array}$ & $\begin{array}{l}0,0004 \\
(1,381)\end{array}$ \\
\hline Adjusted R ${ }^{2}$ & $0,129^{*}$ & $0,052^{* *}$ & $0,050^{* *}$ & $0,131^{*}$ & $0,087^{*}$ \\
\hline
\end{tabular}

Notes:

* significant level of $1 \%$

** significant level of 5\%

*** significant level of $10 \%$

$\mathrm{Vr}=$ security residual variance 


\section{The Economic Consequence of Earnings Quality}

The economic consequence of earnings quality showed that the formulation of relevant measurement for earnings quality for the future research were the measurement of earnings quality related to the relationship between earnings and the cash flow, while the measurement related to the series of last year and current earnings turned to be weak (persistance dan predictability) (Bauwhede, 2001; Bradshaw et al., 2001, 2002).

The relationship between the security residual variance as a proxy of information asymmetry with the three attributes of earnings quality mentioned above showed a positive relationship (Entwistle and Phillips, 2003). The research of Francis et al. (2004) showed the similar findings, a positive relationship among accrual quality, persistance and smoothness towards the cost of capital, while the predictability had a negative relationship. This is different from what Cohen (2003) found that there was a negative relationship between the quality of the financial statement reporting and the information asymmetry.

From the three attributes of earnings quality which had a relationship with the information asymmetry, it was found out that, by conducting J testing, the accrual quality was superior to the other two attributes of earnings quality, while the attribute of smoothness and factorial earnings quality did not superior to each other (Ball, 2005). This finding supports the research conducted by Dechow and Dichev (2002) which introducing the new measurement of the earning quality called as accrual quality.

\section{CONCLUSION AND SUGGESTION \\ Conclusion}

The conclusions of the research were presented as the followings:

1. There was a difference among the attributes of earnings quality so that there was no overlapping among the four attributes of earnings quality. This was because the degree of overlap was not more than 0,5 . The analysis factor of the four attributes mentioned above resulted in one attribute of earnings quality namely factorial earnings quality. The formation of factorial earnings quality came from three components of attributes namely accrual quality, predictabilility and smoothness.

2. The result of testing the determinant factors of earning quality showed that the attribute of accrual quality was influenced by sales volatility, company performance, leverage, and industry classification. The attribute of persistence was influenced by the operation cycle, the company size and leverage. The attribute of predictability was influence by the sales volatility, company size, company performance, liqui dity and leverage. Smoothness was influenced by the sales volatility, company size and leverage. The factorial earnings quality was influenced by the factor of operation cycle, sales volatility, company size, leverage, and industry classification.

3. The result of testing the economic consequence of earnings quality showed that three attributes of earnings quality associated with the economic consequence namely accrual quality, smoothness and factorial earnings quality. Those three models showed that the accrual quality was superior to the smoothness and factorial earnings quality. Meanwhile, the attribute of smoothness and the factorial earnings quality was not superior to each other.

\section{Suggestion}

The limitations of the research were pre- sented as the followings:

1. The period of reseach sample betwen 2005 until 2010, where the period was implementation of accounting standards by generally accepted accounting principles in Indonesia. The year of observation can be extended for the future 
research to implementation of new accounting standards version of international financial reporting standards (IFRS).

2. The sample of the research is manufacturing firms, not all firms in Indonesian capital market. Two conditions above not disain in this research. Further research can be developed in this research by involving the variable of holding company matters and the company which conduct restructurization.

\section{REFERENCES}

Amstrong, C. S., M. E. Bath, A. D. Jagolinzer, and E.J. Riedel. 2011. Working Paper.

Ball, R. 2005. IFRS: Pros and Cons for Investors. Working Paper 1-65.

Ball, R. and L. Shivakumar. 2002. Earnings Quality in U.K. Private Firms. Working Paper, London Business School 1-53.

Barone, G. 2002. Perceptions of Earnings Quality and Their Association With The Cost of Equity Capital. Working Paper, Univeristy of Wisconsin.

Barth, M. E., D. P. Cram, and K. K. Nelson. 2001. Accrual and The Prediction of Future Cash Flows. The Accounting Review 76(1): 27-58.

Barth, M. and W. Landsman. 2003. Cost of Capital and The Quality of Financial Statement Information. Working Paper, Stanford University and University of North Carolina.

Bauwhede, H. V. 2001. What Factors Influence Financial Statement Quality? A Framework and Some Empirical Evidence. Working Paper, Naamsestraat, 1-6.

Boonlert-U-Thai, K. 2004. Earnings Attri butes and Investor Protection: International Evidence, Working Paper, Oklahoma State University 1-44.

Bradshaw, M. T., S. Richardson, and R. G. Sloan. 2001. Earnings Quality and Financial Reporting Credibility: An Empirical Investigation. Journal of Accounting Research 39, June.
Bradshaw, M. T., S. Richardson, and R. G. Sloan. 2002. GAAP Versus The Street: An Empirical Assesment of Two Alternative Definitions of Earnings. Journal of Accounting Research 40(1): 4166.

Brief, R. P. 2002. Consevative Accounting and Earnings Quality. Working Paper...?

Brown, L. D. and K. Sivakumar. 2001. Comparing the Quality of Three Earnings Measures. Working Paper, Georgia State University 1-37.

Callahan, C. M., C. M. C. Lee, and T. L. Yohn. 1997. Accounting Information and Bid-Ask Spread. Accounting Horizon 11(4): 50-60.

Chambers, D. J. 2003. Earnings Persistence and Accrual Anomaly. Working Paper, University of Illinois at UrbanaChampaign 1-29.

Chan, K., L. Chan., N. Jegadeesh, and J. Lakonishok. 2001. Accrual Qulity and Stock Returns: The Evidence from Accruals. Working Paper, National Taiwan University and University of Illinois.

Christensen, H. B., E. Lee, and M. Walker. 2008. Incentive or Standards: What Determinants Accounting Quality Changes around Adoption. Working Paper 1-41.

Christensen, P. O., G. A. Feltham, and F. Sabac. 2005. A Contracting Perspective on Earnings Quality. Journal of Accounting and Economics 39: 265-294.

Cohen, D. A. 2003. Quality of Financial Reporting Choice: Determinants and Economic Consequences. Working Paper, Northwestern University.

Collins, D. W. and P. Hribar. 2000. EarningsBased and Accrual-Based Market Anomalies: One Effect or Two? Journal of Accounting and Economics 29: 101-123.

Cornell, B. and W. R. Landsman. 2003. Accounting Valuation: Is Earnings Quality an Issue?. Financial Analysts Journal 20-28.

Dechow, P. M. 1994. Accounting Earnings and Cash Flow as Measured of Firm 
Performance: The Role of Accounting Accruals. Journal of Accounting and Economics 18: 3-42.

Dechow, P. M. and I. D. Dichev. 2002. The Quality of Accruals and Earnings: The Role of Accrual Estimation Errors. The Accounting Review, Suplement 1-47.

Dechow, P. M., S. P. Kothari, and R.L. Watts. 1998. The Relation Between Earnings and Cash Flow. Journal of Accounting and Economics 25: 133-168.

DeFond, M. L. and C. W. Park. 2001. The Reversal of Abnormal Accruals and the Market Valuation of Earnings Surprises. The Accounting Review 73(3): 375-404.

Diamond, D. and R. Verrechia. 1991. Disclosure, Liquidity, and The Cost of Capital. Journal of Finance 46: 1325-1359.

Dierkens, N. 1991. Information Asymmetry and Equity Issues. Journal of Financial and Quantitative Analysis 26 (2): 181-199.

Easley, D., S. Hvidkjaer, and M. O'Hara. 2002. Is Information Risk a determinant of Asset Returns?. The Journal of Finance LVII(5): 2185-2221.

Easley, D. and M. O'Hara. 2003. Information and the Cost of Capital. Working Paper, Cornell University 1-54.

Entwistle, G. M. and F. Phillips. 2003. Relevance, Reliability, and Earnings Quality Debate. Issues in Accounting Education 18(1): 79-84.

Fairfield, P. M. and T. L. Yohn. 2000. Are Cash Earnings Better than Accrued Earnings?. Working Paper, The Robert Emmett McDonough School of Business, Georgetown University 1-25.

Fairfield, P. M. and J. S. Whisenant. 2001. Using Fundamental Analysis to Assess Earnings Quality: Evidence from the Center for Financial Research and Analysis. Journal of Accounting, Auditing and Finance 16(4): 273-295.

Francis, J., R. LaFond, P. Olsson, and K. Schipper. 2003a. The Market Pricing of Earnings Quality, Working Paper, Fuqua School of Business, Duke University 142.
Francis, J. R. LaFond, P. M. Olsson, and K. Schipper. 2003b. Costs of Equity and Earnings Attributes, Working Paper, Fuqua School of Business, Duke University 1-42.

Francis, J., R. LaFond, P. M. Olsson, and K. Schipper. 2004. Costs of Equity and Earnings Attributes, The Accounting Review 79(4): 967-1010.

Gujarati, D. N. 2003. Basic Econometrics. Fourth edition, New York, McGraw Hill.

Gu, Z. Y., C. J. Lee, and J. G. Rosett. 2002. Information Environment and Accrual Volatility. Working Paper, A.B. Freeman School of Business, Tulane University 123.

Hyan, C. 1995. The Information Content of Losses. Journal of Accounting and Economics 20: 125-153.

Healy, P. M. and K. G. Palepu. 2001. Information Asymmetry, Corporate Disclosure, and The Capital Markets: A Review of The Empirical Disclosure Literature. Journal of Accounting and Economics 31: 405-440.

Hoitash, R., M. Krishman, and S. Sankaraguruswamy. 2002. Earnings Quality and Price Quality. Working Paper, Rutgers University 1-27.

Kamp, B. 2002. Earnings Quality Assessment by a Sell-Side Financial Analyst. Issues in Accounting Education 17(4): 361368.

Kim, O., and R. Verrecchia. 1994. Market Liquidity and Volume Around Earnings Announcements. Journal of Accounting and Economics 17: 41-67.

Kirschenheiter, M. and N. Melumad. 2002. Earnings Quality and Smoothing. Working Paper, Columbia University 1-51.

Largay III, J. A.. 2002. Lessons from Enron. Accounting Horizons 16(2): 153-156.

Lev, B. and R. Thiagarajan. 1993. Fundamental Information Analysis. Journal of Accounting Research 31(2): 190-215.

Lougee, B. A. and C. A. Marquardt. 2002. Earnings Quality and Strategic Disclosure: An Empirical Examination of 'Pro Forma' 
Earnings. Working Paper, University of California 1-38.

Leuz, C. and R. E. Verrechia. 2004. Firms' Capital Allocation Choices, Information Quality, and the Cost of Capital. Working Paper, The Wharton School, University of Pennsylvania 1-22.

Leuz, C. and R. E. Verrechia. 2000. The Economic Consequences of Increased Disclosure. Journal of Accounting Research 38 (Supplement): 91-126.

McNichols, M. F. 2002. Discussion of the Quality of Accruals and Earnings: The Role of Accrual Estimation Errors. The Accounting Review 77 (Supplement): 6169.

Miller, P. B. W. 2002. Quality Financial Reporting. Journal of Accountancy April: 70-74.

Palepu, K. G., P. M. Healy, V. L. Bernard. 2000. Business Analysis and Valuation, Using Financial Statement. 2nd ed. SouthWestern Colledge Publishing. Cincinnati, Ohio.

Penman, S. H. 2003. The Quality of Financial Statement: Perspectives from the Recent Stock Market Bubble. Accounting Horizons 70 (Supplement): 77-96.
Penman, S,H. and X. Zhang. 2002. Accounting Conservatism, the Quality of Earnings, and Stock Returns. The Accounting Review 77(4): 237-264.

Richardson, S. A., R. G. Sloan, M. T. Soliman, dan I. Tuna. 2003. Accraul Reliability, Earnings Persistence and Stock Prices. Working Paper, University of Michigan Business School 1-60.

Richardson, S. A. 2003. Earnings Quality and Short Sellers. Accounting Horizons 70 (Supplement): 49-61.

Schipper, K. and L. Vincent. 2003. Earnings Quality. Accounting Horizons 7 (Supplement): 97-110.

Schipper, K. 2004. Earnings Quality, Working Paper in Asia Pacific. Journal of Accounting and Economics Conference. January. Kuala Lumpur, Malaysia.

Sloan, R. G. 1996 Do Stock Prices Fully Reflect Information in Accruals and Cash Flow About Future Earnings?. The Accounting Review 71(3): 289-315.

Willekens. 2006. Attribute Differences bet ween US GAAP and IFRS Earnings: An Exploratory Study. Working Paper 1-35. 